\title{
NOVÉ POZNATKY O NEOVULKANITU V POHOŘI U ODER (OKRES NOVÝ JIČíN)
}

\author{
New knowledge about a neovolcanic rock at Pohoř near Odry (district Nový Jičín) \\ Vojtěch Šešulka, Radka Drápalová, Antonín Přichystal, Dalibor Všianský \\ Ústav geologických věd, PřF MU, Kotlářská 2, 61137 Brno; e-mail: 78302@mail.muni.cz
}

(25-12 Hranice)

Key words: Cenozoic volcanism, (Oligocene), olivine melilitite, geomagnetic survey, volcanic dyke

\begin{abstract}
The dyke on the Pohor hill represents the most southeastern occurrence of Cenozoic volcanic rock in the Bohemian Massif. It has been studied since the second half of the $19^{\text {th }}$ century, when it was discovered during a construction of railroad. Since that time the dyke has been considered to be hidden and there was no actual data about the site. We have carried out a ground magnetic survey to revise the location and shape of the volcanic body. Several boulders of the volcanic rock have been sampled. According to new petrographical and geochemical analyses we have classified the rock from Pohor as an olivine melilitite.
\end{abstract}

\section{Úvod}

Lokalita Pohoř představuje jeden z mnoha menších výskytů severomoravských a slezských neovulkanitů. Objevena byla v roce 1883 př̀ stavbě železniční trati ze Suchdola nad Odrou do Budišova nad Budišovkou. Podrobný popis žíly čedičové horniny, dřive považované za pikrit, podává Pacák (1928). Ve své obsáhlé publikaci o severomoravských neovulkanitech uvádí, že již při jeho návštěvě o rok dřive byla lokalita zaniklá. Odkryv čediče v železničním zářezu byl při výstavbě železnice sanován pomocí opěrné zdi a již samotný O. Pacák byl odkázán pouze na ústní sdělení pamětníků. Od jeho doby nebyla lokalitě věnována ostatními autory př́lišná pozornost, ačkoliv několik málo zmínek o pohořském „bazaltu“ lze v literatuře vysledovat. Podrobnější geochemickou specifikaci přinášejí Fediuk a Fediuková (1985). Také na podrobné geologické mapě měřítka $1: 25000$ (Dornič et al. 1971) je na jz. úpatí kopce Pohoř zaznačen menší čedičový výskyt. Naopak v nejnovějši geologické mapě stejného měřítka od Gilíkové et al. (2007) žádný neovulkanit zaznačen není.

$\mathrm{V}$ loňském roce byl na vrchu Pohoř za účelem upřesnění lokalizace a průběhu čedičové žíly proveden pozemní geomagnetický průzkum. $V$ průběhu měření byly nalezeny menší balvany bazické vyvřelé horniny, z nichž byly odebrány horninové vzorky, které byly podrobeny sérii petrografických a geochemických analýz.

\section{Geologická situace}

Vulkanická žíla na úpatí vrchu Pohoř je nejjihovýchodnějším zjištěným povrchovým výskytem (původně známá jen v zářezu železnice) kenozoického vulkanismu na Českém masivu. Jedná se o drobné těleso prorážející břidlice, prachovce a droby hradecko-kyjovického souvrství kulmu Nízkého Jeseníku (Dornič et al. 1971, Otava et al. 2001, Gilíková et al. 2007). Obecně bývají severo- moravské a slezské neovulkanity často děleny na vnitřní a vnější skupinu [toto rozdělení pochází z přelomu 19. a 20. století a bylo později hojně přejímáno dalšími autory, např. Pacákem (1928) nebo Kopeckým (1964)]. Hlavními kritérii pro toto rozdělení jsou geografická poloha (j. a s. od okrajového zlomu lugika) a stáŕí vulkanitů (plio-pleistocenní stáŕí nebo starší). Proto je zařazení Pohoře do jedné z těchto dvou skupin problematické. Lokalita je prostorově pravděpodobně vázána, stejně jako vulkanická centra vnitřní řady, na pokračování bělského zlomu, nicméně její nově zjištěné stáří 32,3 $\pm 1,4 \mathrm{Ma}$ (Ulrych et al., v tisku) je obdobné jako u neovulkanitů z řady vnější. Toto nově stanovené stárí je do jisté míry překvapující, nebot pohořský čedič byl dřive na základě prostorové příbuznosti s takto starými vulkanity ze střední části Nízkého Jeseníku kladen do plio-pleistocenního období (Dornič et al. 1971).

\section{Metodika}

Za účelem určení polohy, př́ípadně i tvaru „zapomenuté“ vulkanické struktury na úpatí vrchu Pohoř, byla aplikována magnetická metoda geofyzikálního průzkumu. Při pozemním měření absolutní hodnoty magnetického pole $\mathrm{T}$ byla použita aparatura Cs-magnetometr SM-5 Navmag (Scintrex, Kanada). Tento prŕístroj umožňuje kontinuální záznam změn a anomálií magnetického pole Země s přesností $0,1 \mathrm{nT}$, které jsou vyvolané mj. různě magnetizovanými horninovými tělesy. Frekvence záznamu dat byla nastavena na dvě měření za vteřinu. Lokalizace měřických túr byla provedena vestavěným GPS senzorem, který dosahuje přesnosti jednotek metrů. Zpřesnění polohy bylo navíc provedeno pomocí ruční GPS Trimble Juno ST. Měřičské túry dosáhly celkové délky více než $10 \mathrm{~km}$ a pokryly plochu o rozloze zhruba $1,5 \mathrm{~km}^{2}$.

Ke zjištění minerálního složení odebrané horniny byl použit polarizační mikroskop a prášková RTG 
difrakční analýza na aparatuře Bruker D8 Advance s Cu anodou $\left(\lambda_{\mathrm{Ka}}=1,54184 \AA\right.$ ) a variabilními divergenčními clonami při $\Theta-\Theta$ reflexní Bragg-Brentano parafokusační geometrii v úhlovém rozmezí $6-80^{\circ} 2 \Theta$. Chemické složení horninotvorných minerálů bylo zjištováno na elektronové mikrosondě Cameca SX-100 v Laboratoři elektronové mikroskopie a mikroanalýzy na ÚGV PřF MU (operátor Š. Benedová). Měření bylo provedeno při urychlovacím napětí $15 \mathrm{kV}$, průměrném elektronovém svazku $5 \mu \mathrm{m}$ a proudu $10 \mathrm{nA}$. Dále byla hornina podrcena na požadovanou frakci v achátovém mlýnku. Na části této frakce bylo silikátovou analýzou zjištěno množství hlavních oxidů, analýzu provedl P. Kadlec na ÚGV PřF MU. Druhá část téže horniny byla poslána do laboratoří AcmeLabs v Kanadě na celohorninovou chemickou analýzu. Zde bylo metodou ICP-ES/-MS zjištěno zastoupení hlavních oxidů, stopových prvků a prvků vzácných zemin. Výsledky těchto analýz byly vyhodnoceny v programu GCDkit (Janoušek et al. 2006).

\section{Geofyzikální průzkum}

Ačkoliv geofyzikální měření proběhlo na větší ploše, vzhledem k terénním a vegetačním podmínkám na lokalitě bylo pro interpretaci samotné polohy a směru vulkanické žíly použito pěti zhruba paralelních profilů o délce 150 až

300 m. Předpokladem úspěšné identifikace struktury byl dostatečný kontrast mezi magnetickou susceptibilitou bazaltoidní horniny $\left(26-29 \times 10^{-3} \mathrm{SI}\right)$ a okolních kulmských břidlic a drob $\left(0,1-0,2 \times 10^{-3} \mathrm{SI}\right)$.

Při pohledu na přiloženou mapu s vynesenými hodnotami (obr. 1) lze poměrně dobře vysledovat průběh žíly paralelní s okrajovým zlomem Oderských vrchů, tedy ve směru SV-JZ, v délce asi $300 \mathrm{~m}$. Měření bohužel nebylo možné provést bliže k železniční trati, ovšem je zřejmé, že údaje o poloze čedičového tělesa v Pacákově náčrtu z roku 1928 i v geologické mapě 1 : 25000 (Dornič et al. 1971) nejsou přesné. Ani v horní části území, sv. směrem k obci Pohoř, nebylo pokračování žíly zastiženo. Je tedy pravděpodobné, že žíla ve vrcholové partii vykliňuje a ztrácí se.

\section{Petrografie a geochemie}

Povrch odebraných vzorků je pokryt žlutošedou patinou, která vznikla dlouhodobým vystavením horniny povětrnostním vlivům. Na čerstvém lomu je hornina tmavošedá, kompaktní, s mikroporfyrickou strukturou. Ve výbrusu je zřetelná porfyrická struktura, ve které jsou fenokrysty tvořené olivínem a pyroxenem. Základní hmota je holokrystalická a obsahuje pyroxen, olivín, nefelín, melilit a spinelidy. Zjištěny byly i minerály serpentinové skupiny, pyrit a stronciem bohatý baryt. Vyrostlice bezbarvého olivínu (dosahují veli-

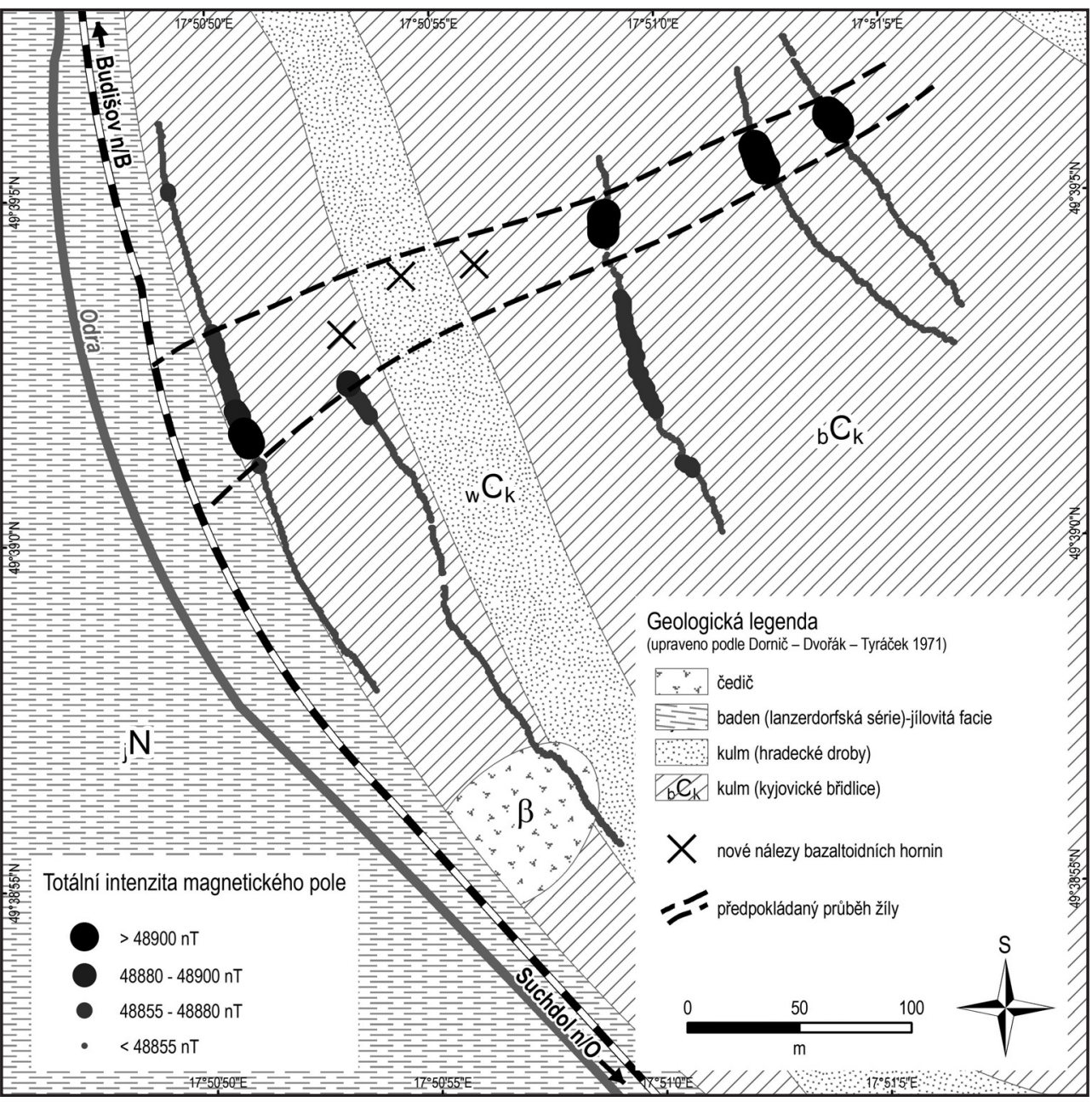

Obr. 1: Mapa vrchu Pohoř s vynesenými hodnotami geofyzikálního měření a pozicí odebraných vzorků. Fig. 1: Map of the Pohoř hill with geophysical data and location of sampled rocks. kosti až $500 \mu \mathrm{m})$ jsou automorfně omezené a homogenní. Některá zrna jsou resorbována a částečně serpentinizována na okrajích a podél puklin. Elektronovou mikrosondou bylo zjištěno, že se jedná o hořečnatý olivín, tedy forsterit $\left(\mathrm{Fo}_{85-87}\right)$. Množství olivínových vyrostlic převládá nad vyrostlicemi velmi slabě hnědozelených klinopyroxenů, které jsou automorfně omezené s velikostí až $200 \mu \mathrm{m}$. U některých pyroxenů je viditelná oscilační či sektorová zonálnost, která má $\mathrm{v}$ některých zrnech strukturu přesýpacích hodin. Přepočet mikrosondových analýz (tab. 1) odhalil, že se jedná o vyrostlice diopsidu. $V$ prípadě oscilačně zonálního klinopyroxenu je okrajová část mírně bohatší Fe a Ti než část stř̌edová. 


\begin{tabular}{|c|c|c|c|c|c|}
\hline & $1 / 1$ & $2 / 1$ & $4 / 1$ & $6 / 1$ & $21 / 1$ \\
\hline $\mathrm{SiO}_{2}$ & 43,27 & 39,68 & 45,60 & 45,17 & 44,39 \\
\hline $\mathrm{TiO}_{2}$ & 3,76 & 5,17 & 2,90 & 3,45 & 3,54 \\
\hline $\mathrm{Al}_{2} \mathrm{O}_{3}$ & 10,26 & 12,43 & 7,04 & 6,94 & 8,25 \\
\hline $\mathrm{Cr}_{2} \mathrm{O}_{3}$ & 0,34 & 0,02 & 0,01 & 0,02 & 0,00 \\
\hline $\mathrm{FeO}$ & 6,40 & 7,48 & 6,99 & 7,46 & 6,10 \\
\hline $\mathrm{MnO}$ & 0,11 & 0,06 & 0,14 & 0,18 & 0,10 \\
\hline $\mathrm{MgO}$ & 12,01 & 10,82 & 12,63 & 12,37 & 12,96 \\
\hline $\mathrm{CaO}$ & 23,57 & 23,76 & 23,95 & 23,54 & 24,44 \\
\hline $\mathrm{Na} 2 \mathrm{O}$ & 0,44 & 0,44 & 0,43 & 0,51 & 0,33 \\
\hline suma & 100,16 & 99,86 & 99,69 & 99,64 & 100,11 \\
\hline \multicolumn{6}{|c|}{ přepočet kationtů na 6 atomů $O$} \\
\hline Si & 1,62 & 1,51 & 1,72 & 1,71 & 1,67 \\
\hline $\mathrm{Al}(\mathrm{T})$ & 0,38 & 0,49 & 0,28 & 0,30 & 0,33 \\
\hline Al (M1) & 0,08 & 0,07 & 0,03 & 0,01 & 0,03 \\
\hline $\mathrm{Fe}^{3+}$ & 0,20 & 0,25 & 0,20 & 0,18 & 0,22 \\
\hline $\mathrm{Cr}$ & 0,01 & 0,00 & 0,00 & 0,00 & 0,00 \\
\hline Ti & 0,11 & 0,15 & 0,08 & 0,10 & 0,10 \\
\hline $\mathrm{Fe}^{2+}$ & 0,01 & 0,00 & 0,02 & 0,06 & 0,00 \\
\hline Mn & 0,00 & 0,00 & 0,00 & 0,01 & 0,00 \\
\hline $\mathrm{Mg}$ & 0,67 & 0,61 & 0,71 & 0,70 & 0,73 \\
\hline $\mathrm{Ca}$ & 0,95 & 0,97 & 0,97 & 0,95 & 0,98 \\
\hline $\mathrm{Na}$ & 0,03 & 0,03 & 0,03 & 0,04 & 0,02 \\
\hline$\Sigma$ kat. & 4,06 & 4,08 & 4,04 & 4,06 & 4,08 \\
\hline
\end{tabular}

Tab. 1: Reprezentativní mikrosondové analýzy pyroxenů.

Tab. 1: Representative microprobe analyses of pyroxenes.

Opticky nebylo možné identifikovat, který minerál vyplňuje prostor mezi zrny základní hmoty. Mikrosondovou analýzou se prokázalo, že se jedná o nefelín. Hojné šedomodré krystaly melilitu se v hornině vyskytují ve formě lišt. $\mathrm{V}$ těchto lištách lze pozorovat drobné tmavé jehličky směřuící od okraje ke středu zrn, tzv. cvočkovitou strukturu. Dále byly analyzovány spinelidy, které ve výbrusu tvoří automorfně omezená zrna. Část z nich odpovídá Cr-spinelům a část Ti-magnetitům. Některé Cr-spinely jsou lemovány magnetitem. Pacákem (1928) byl v hornině popsán minerál haüyn, ten však nebyl zjištěn opticky ani pomocí RTG difraktometru. Druhou zmíněnou metodou

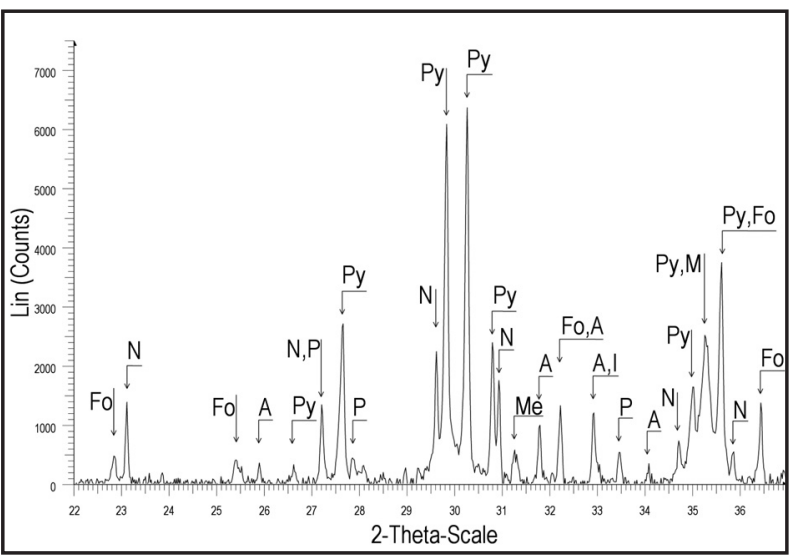

Obr. 2: Difraktogram vulkanitu z Pohoře; výřez oblasti 22 $37^{\circ} 2 \Theta ; \mathrm{P}$ - phillipsit, A - apatit, $\mathrm{Na}$ - natrolit, Fo - forsterit, $\mathrm{M}$ - magnetit, $\mathrm{N}$ - nefelín, Py - augit/diopsid, Me - melilit, I - ilmenit. Fig. 2: Diffractogram of the rock from Pohor; cut-out of the area $22-37^{\circ} 2 \Theta ; \mathrm{P}$ - phillipsite, $\mathrm{A}$ - apatite, $\mathrm{Na}$ - natrolite, Fo forsterite, $\mathrm{M}$ - magnetite, $\mathrm{N}$ - nephelinite, $\mathrm{Py}$ - augite/diopside, $\mathrm{Me}$ - melilite, I - illmenite.

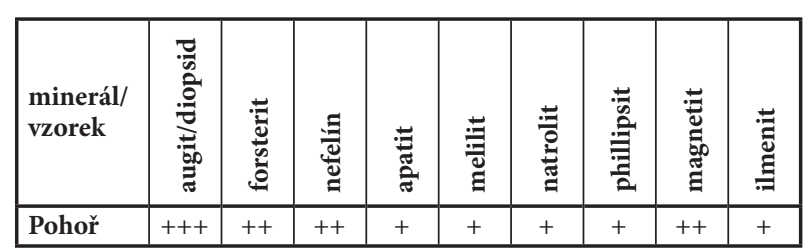

Tab. 2: Kvalitativní a semikvantitativní rentgenová analýza vzorku Pohoř $(+++,++,+$ relativní zastoupení minerálů).

Tab. 2: X-ray analysis of the sample from Pohor $(+++,++,+$ relative mineral content).

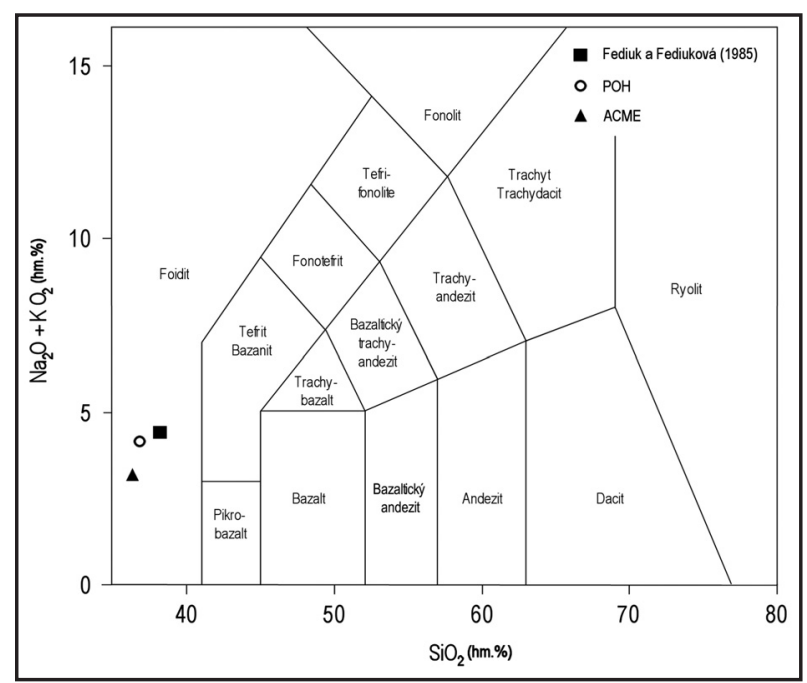

Obr. 3: TAS diagram (Le Bas et al. 1986) s vyznačenými horninovými analýzami z Pohoře; analýza publikovaná Fediukem a Fediukovou (1985), POH - silikátová analýza provedená na ÚGV PřF MU a analýza z Acme.

Fig. 3: TAS diagrame (Le Bas et al. 1986) with marked rock analyses from Pohoř; 1 - Fediuk - Fediuková (1985), 2 - new data.

(obr. 2) bylo stanoveno kvalitativní a semikvantitativní zastoupení identifikovaných krystalických fází (tab. 2). Podle odhadu této analýzy by měl být $\mathrm{v}$ hornině nejvíce zastoupen klinopyroxen, dále forsterit, nefelín, magnetit, melilit, ilmenit, apatit, natrolit a phillipsit.

Hornina byla Pacákem (1928) mineralogicky popsána a pojmenována jako haüynicko-meliliticko-nefelinický čedič. Fediuk a Fediuková (1985) interpretují název podle tehdejši terminologie jako haüynicko-melilitický olivinický nefelinit a zároveň ve své práci uvádějí dosud nepublikovanou analýzu vzorku ze sbírek katedry petrologie PřF UK.

Po vynesení výsledků nových analýz do TAS diagramu (podle Le Bas et al. 1986) spadá hornina do pole foiditu (obr. 3), což koresponduje s analýzou publikovanou Fediukem a Fediukovou (1985). Jak ukázala mikrosondová měření a RTG difrakční analýza, $\mathrm{z}$ foidů je zastoupen nefelín. Hornina obsahuje více než $10 \%$ modálního olivínu a je larnit-normativní, obsahuje tedy minerál melilit. Vzhledem $k$ tomu, že melilitu je více než $10 \%$, hornina by měla být na základě klasifikace Le Maitra et al. (2002) označena jako olivinický melilitit. Srovnání zastoupení hlavních oxidů uvedené $\mathrm{v}$ literatuře a nových analýz je $\mathrm{v}$ tab. 3.

Obrázek 4 ukazuje porovnání množství inkompatibilních prvků a REE pohořského vzorku (tab. 4) s dalšími severomoravskými neovulkanity (Foltýnová 2003), které 


\begin{tabular}{|l|c|c|c|}
\hline vzorek & Acme & POH & $\begin{array}{c}\text { Fediuk - Fediuková } \\
(1985)\end{array}$ \\
\hline $\mathrm{SiO}_{2}$ & 36,37 & 36,90 & 38,27 \\
\hline $\mathrm{TiO}_{2}$ & 2,88 & 2,70 & 3,11 \\
\hline $\mathrm{Al}_{2} \mathbf{O}_{3}$ & 11,08 & 11,07 & 10,86 \\
\hline $\mathrm{Fe}_{2} \mathbf{O}_{3}$ & 11,64 & 5,08 & 4,74 \\
\hline $\mathbf{F e O}$ & - & 6,71 & 7,49 \\
\hline $\mathbf{M n O}$ & 0,22 & 0,25 & 0,22 \\
\hline $\mathbf{M g O}$ & 11,92 & 13,49 & 16,17 \\
\hline $\mathbf{C a O}$ & 14,81 & 14,46 & 10,12 \\
\hline $\mathbf{N a} \mathbf{O}_{2}$ & 2,04 & 3,20 & 3,36 \\
\hline $\mathbf{K}_{2} \mathbf{O}$ & 1,01 & 0,91 & 1,00 \\
\hline $\mathbf{P}_{2} \mathbf{O}_{5}$ & 1,47 & 1,68 & 1,37 \\
\hline $\mathbf{H}_{2} \mathbf{O}^{-}$ & - & 0,64 & 0,48 \\
\hline $\mathbf{H}_{2} \mathbf{O}^{+}$ & - & 2,42 & 2,58 \\
\hline $\mathbf{S}$ & - & 0,19 & - \\
\hline $\mathbf{C O}$ & - & 0,34 & 0,24 \\
\hline $\mathbf{L O I}$ & 5,80 & - & - \\
\hline suma & 99,24 & 100,04 & 100,01 \\
\hline
\end{tabular}

Tab. 3: Hlavní oxidy (hm. \%) zastoupené v melilititu z Pohoře, Acme - analýza ICP-MS/-ES, Fe je uvedeno jako sumární $\mathrm{Fe}_{2} \mathrm{O}_{3}$; $\mathrm{POH}$ - silikátové analýzy provedené na ÚGV PřF MU a analýza publikovaná Fediukem a Fediukovou (1985).

Tab. 3: Main oxides (wt. \%) in the melilitite from Pohor - ICPMS/-ES analysis, $\mathrm{Fe}$ is as total $\mathrm{Fe}_{2} \mathrm{O}_{3}$; $\mathrm{POH}$ - silicate analyses (ÚGV PřF MU) and analysis by Fediuk and Fediuková (1985).

byly rovněž analyzovány metodou ICP-MS/-ES v Acme. $\mathrm{Z}$ tohoto diagramu je patrné, že naprostá většina těchto prvků vystupuje při horní hranici distribučního pole pro severomoravské neovulkanity. Zvýšené obsahy $\mathrm{Pb}$ s velkou pravděpodobností souvisí s výskyty galenitu v nejbližším okolí, který byl od středověku těžen.

\section{Diskuze a závěr}

Pomocí geomagnetického průzkumu se podařilo určit, že vulkanit, o němž byly z minulosti známy pouze kusé informace, tvoří žílu o délce několika set metrů. Žíla je orientována souběžně s okrajovým zlomem Oderských vrchů a podle dosud známých poznatků nepřekračuje údolí

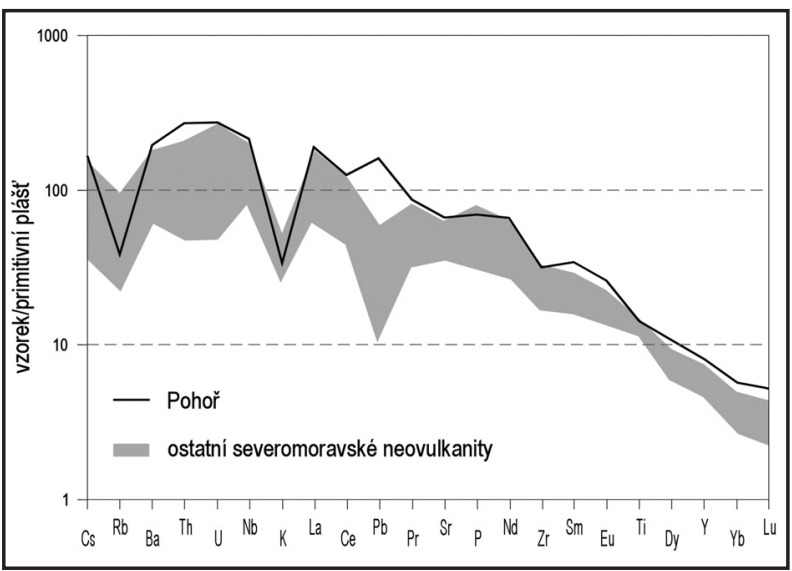

Obr. 4: Primitivním pláštěm normalizované (podle Sun - McDonough 1989) složení pohořského melilititu a ostatních výskytů (Foltýnová 2003) severomoravských a slezských neovulkanitů. Fig. 4: Primitive mantle normalization (after Sun - McDonough 1989) of melilitite from Pohoř and the range of other neovolcanic rocks (Foltýnová 2003) from northern Moravia and Silesia.

\begin{tabular}{|l|c|l|c|}
\hline & Acme & & Acme \\
\hline As & 4,1 & V & 313,0 \\
\hline Au & 1,2 & W & 0,6 \\
\hline Ba & 1344,0 & Y & 36,9 \\
\hline Be & 2 & Zn & 75,0 \\
\hline Co & 49,5 & Zr & 351,5 \\
\hline Cs & 1,2 & La & 128,2 \\
\hline Cu & 71,8 & Ce & 225,3 \\
\hline Ga & 17,4 & Pr & 24,1 \\
\hline Hf & 6,8 & Nd & 89,9 \\
\hline Mo & 1,9 & Sm & 15,2 \\
\hline Nb & 155,0 & Eu & 4,4 \\
\hline Ni & 164,4 & Gd & 12,5 \\
\hline Pb & 11,3 & Tb & 1,6 \\
\hline Rb & 23,9 & Dy & 7,9 \\
\hline Sc & 25,0 & Ho & 1,3 \\
\hline Sr & 1389,0 & Er & 3,4 \\
\hline Ta & 8,2 & Tm & 0,5 \\
\hline Th & 23,2 & Yb & 2,8 \\
\hline U & 5,7 & Lu & 0,4 \\
\hline
\end{tabular}

Tab. 4: Obsahy stopových prvků (ppm) v melilititu $\mathrm{z}$ vrchu Pohoř (stanoveno v Acme). Tab. 4: Content of trace elements (ppm) in the melilitite from Pohoř (Acme).

řeky Odry směrem k JZ. Lze tedy předpokládat ukončení žilné struktury na zlomu paralelním s řekou Odrou, tj. zlom v pokračování bělského zlomu (směr SZ-JV). Zda-li je žíla v podloží neogenních sedimentů ukončena ostře zlomem či vykliňuje pozvolna ještě před ním nebo snad pokračuje na druhém břehu řeky, není možné ze získaných indicií určit. Náznaky pro její pokračování směrem $\mathrm{k}$ Veselskému kopci lze však spatřovat ve starších geofyzikálních pracích (Šalanský - Manová 2001), resp. geomorfologii dna Oderské kotliny (Otava et al. 2001).

Samotná vulkanická hornina $\mathrm{z}$ Pohoře představuje výjimečný výskyt jak stář́m, tak pokud jde o minerální složení. Jedná se o první doložený výskyt melilititu v moravskoslezské oblasti. Nejbližší výskyty melilitických hornin na Českém masivu jsou známy z oblasti oháreckého riftu, kde spadají do preriftové fáze tektono-vulkanického vývoje, tedy do svrchní kř́idy (např. Kopecký 1978, Ulrych et al. 2008). Na základě zjištěného chemického složení a výrazně vyššího stáří vzorku z Pohoře (ve srovnání s ostatními vulkanity Nízkého Jeseníku) lze tedy usuzovat, že by se mohlo jednat o iniciální fázi severomoravského vulkanizmu.

Další výzkum a rozšíření geofyzikálního průzkumu i na pravý břeh řeky Odry by mohly v budoucnu přinést cenné poznatky o kenozoické vulkanické činnosti a tektonice na okraji Nízkého Jeseníku.

\section{Poděkování}

Tato práce byla vypracována za finanční podpory výzkumného záměru MSM0021622427 „Interdisciplinární centrum výzkumů sociálních struktur pravěku až vrcholného středověku“ a GAČR 404/09/H020 „Moravskoslezská škola archeologických doktorských studií II (prohloubení mezioborové spolupráce)“. 


\section{Literatura}

Dornič, J. - Dvořák, J. - Tyráček, J. (1971): Základní geologická mapa 1 : 25 000, list M 33-96-B-a Odry. Ústř. úst. geol. Praha.

Fediuk, F. - Fediuková, E. (1985): Postmezozoické alkalické vulkanity severní Moravy. - Acta Universitatis Carolinae, Geologica, $4,355-382$.

Foltýnová, R. (2003): Geochemicko-petrografická charakteristika neovulkanitů severní Moravy a Slezska. - MS diplomová práce, PřF MU. Brno.

Gilíková, H. - Pálenský, P. - Tomanová Petrová, P. - Otava, J. - Nývlt, D. - Šikula, J. (2007): Základní geologická mapa České republiky $1: 25$ 000, 25-122 Suchdol nad Odrou. - MS, archiv ČGS. Praha.

Janoušek, V. - Farrow, C. M. - Erban, V. (2006): Interpretation of whole-rock geochemical data in igneous geochemistry: introducing Geochemical Data Toolkit (GCDkit). - Journal of Petrology, 47, 6, $1255-1259$.

Kopecký, L. (1964): Neovulkanity Českého masívu. - In: Svoboda, J. et al.: Regionální geologie ČSSR, I-2, 365-408. Nakl. Čs. Akad. Věd, Praha.

Kopecký, L. (1978): Neoidic taphrogenic evolution and young alkaline volcanism of the Bohemian Massif. - Sborník geologických věd, Geologie, 31, 91-124.

Le Bas, M. J. - Le Maitre, R. W. - Streckeisen, A. - Zanettin, B. (1986): A chemical classification of volcanic rocks based on the total alkali-silica diagram. - Journal of Petrology, 27, 745-750.

Le Maitre, R. W. (ed.) - Streckeisen, A. - Zanettin, B. - Le Bas, M. J. - Bonin, B. - Bateman, P. - Bellieni, G. - Dudek, A. - Efremova, S. - Keller, J. - Lameyre, J. - Sabine, P. A. - Schmid, R. - Sørensen, H. - Woolley, A. R. (2002): Igneous Rocks: A Classification and Glossary of Terms. Recommendations of the International Union of Geological Sciences Subcommision on the Systematics of Igneous Rocks. $2^{\text {nd }}$ Edition. - Cambridge University Press, Cambridge - New York. 236 pp.

Otava, J. et al. (2001): Vysvětlivky k základní geologické mapě České republiky 1 : 25 000, 25-121 Odry, 1-69. ČGS. Praha.

Pacák, O. (1928): Čediče Jeseníku a přilehlých území. - Věstník Královské české společnosti nauk, tř́ída II (matematickoprírodovědecká), 1-172.

Sun, S. S. - McDonough, W. F. (1989): Chemical and isotopic systematics of oceanic basalts: implications for mantle composition and precesses. - In: Saunders, A. D. - Norry, M. (eds): Magmatism in Ocean Basins, 42, 313-345. Geological Society London. Special Publication.

Šalanský, K. - Manová, M. (2001): Geofyzikální poměry. - In: Otava, J. et al.: Vysvětlivky k základní geologické mapě České republiky $1: 25$ 000, 25-121 Odry, 18-22. ČGÚ. Praha.

Ulrych, J. - Dostal, J. - Hegner, E. - Balogh, K. - Ackerman, L. (2008): Late Cretaceous to Paleocenemeliliticrocks of the Ohře/ EgerRift in northern Bohemia, Czech Republic: Insights into the initial stages of continental rifting. - Lithos, 101, 141-161.

Ulrych, J. - Ackerman, L. - Balogh, K. - Hegner, E. - Jelínek, E. - Pécskay, Z. - Přichystal, A. - Upton, B. G. J. - Zimák, J. (v tisku): Plio-Pleistocene basanitic and melilititic volcanic series of the Bohemian Massif: geochemistry, petrology and K-Ar ages. - Chemie der Erde. 